\title{
The Influence of Social Economic Status, Discipline, Motivation on Learning Outcomes of Entrepreneurship Creative Products
}

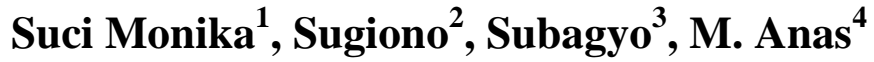 \\ ${ }^{1,2,3,4}$ Masters of Economic Education, Postgraduate, Nusantara PGRI University of Kediri, Indonesia
}

Corresponding Author: Suci Monika

\begin{abstract}
The purpose of this study is to determine the effect of parents' economic status, learning discipline, and student motivation in learning on the learning outcomes obtained in Creative Products and Entrepreneurship subject at Putra Harapan Vocational School of 2019/2020 academic year. This research is a correlation research that is used to determine the cause-andeffect relationship between variable $\mathrm{X}$ and variable Y. 156 respondents are the population of this study with a sample of 30 respondents taken using a simple random sampling technique. Questionnaires and observation sheets are data collection techniques of this research. Furthermore, the data were analyzed using multiple linear regression analysis techniques. This research results $t$ are (1) there is a significant positive effect between parents' economic status on learning outcomes, (2) there is a significant positive effect between learning discipline and learning outcomes, (3) there is no significant effect between motivation and learning outcomes.
\end{abstract}

Keywords: economic status; discipline; motivation; learning outcomes

\section{INTRODUCTION}

Education is lasted a lifetime and begins when a baby is born. Some people think that the experience in life will be more meaningful in formal education, even though the experience that has been gained indirectly did not come through school can be called science which is the result of an education. According to (Indra Azra 2015) education is an activity that allows learning and development everywhere.

Learning activities should involve educators and students in an active setting. Learning activities are primary activities, while secondary activities are activities arranged by educators. By learning, students could show a positive attitude. In an educational institution, success in learning can be seen from the learning outcomes achieved by students (Forijati., Anas, 2020). Learning outcomes can be influenced by parents' socio-economic status, intelligence, motivation, discipline, family environment, student learning methods, health, interests and concerns.

According to (Indrianti, Djaja, and Suyadi 2018) motivation is a stimulus that arises due to encouragement both from within and from outside, so that changes in behavior or activities take place from wanting someone to be better than before. Learning motivation is an important factor that can affect students' learning. There is a desire and willing to succeed, interesting activities in learning, and a conducive learning environment. The previous are indicators of students' learning motivation.

Not only motivation but also learning success and the economic status of parents are also influenced by the learning discipline of students. The learning process arranged by teachers who educate students with various kinds of backgrounds, attitudes and potentials could influence learning habits in participating in learning and 
behavior at school (Artantri, Forijati, Anas, \& Surindra, 2021). Students who wish for high learning outcomes must have a high discipline. This is because high discipline makes students always have the willingness, enthusiasm and responsibility in learning. Discipline in learning must be innate within students.

This is also in line with research conducted by oleh (Rizkiana Senada 1377), which states that there is a partial influence between parents' economic status, motivation, and learning discipline on learning achievement. There is a simultaneous significant effect between parents' economic status, motivation and learning discipline on learning achievement.

SMK Putra Harapan is a private school located at JI. Kartini No. 45 Wonokerto, Piemahan, Kediri. The school is a medium-sized private school. The number of students is not more than 300 students. Every student has different problems. However, the problem experienced by students is discipline. The lack of discipline is caused by several factors, including the lack of students' learning motivation and various backgrounds of the socioeconomic status of each student that will affect their learning outcomes.

Some of the rule violations committed by the students of SMK Putra Harapan like: (1) not attending class, (2) making noise in class, (3) not doing assignments. Students who do a lot of violation are the students of the Motorcycle Engineering and Business major. This is because there is still a transition period from junior high school to vocational school. Therefore, there is still a need to lead the students to have discipline and high motivation.

In this case, the researcher is conducting research on the subjects of Creative Products and Entrepreneurship at SMK Putra Harapan. Creative Products and Entrepreneurship was chosen because these subjects prioritize cognitive, soft skills, and hard skills aspects of students which later aim to be an alternative to emphasize the current unemployment rate. Studentcentered nature is the emphasis of the subject of Creative Products and Entrepreneurship at the SMK level. This is aimed to explore the potential of students freely and be able to produce various kinds of products while still applying positive characters (Fuadi \& Anas, 2019). The subjects of creative products and entrepreneurship are designed in a sustainable manner with the development of the times and technology and do not abandon entrepreneurial values.

In maximizing the supporting of entrepreneurship activities, students are required to bring their own materials from home. This request becomes an obstacle for students, especially financial side, because the most economic status of the parents of each student is in the low condition. The socio-economic status of parents in Putra Harapan Vocational School is middle to lower economic status. This results in decreased discipline and a lack of motivation in learning, so that learning outcomes decrease (Jayanti, Amanah, Artantri, \& Muchson, 2021).

Based on the background above, the research aims to determine the effect of socioeconomic status, discipline and learning motivation on the learning outcomes of Creative Products and Entrepreneurship subjects at SMK Putra Harapan for the academic year 2019/2020.

\section{LITERATURE REVIEW Learning Outcomes}

Learning Outcomes is assessments of the results that have been achieved by each student in the cognitive, affective, and psychomotor domains obtained as a result of the effort of learning activities and are assessed within a certain period.

\section{Parents Social Status}

Basically, several different groups do not limit the social status of parents, but other groups see person's status affect a person's socioeconomic status. The socioeconomic status of parents is a classification 
Suci Monika et.al. The influence of social economic status, discipline, motivation on learning outcomes of entrepreneurship creative products.

of criteria based on the economy, occupation, and education and position possessed by parents in a community environment.

\section{Learning Discipline}

Discipline is a violation that occurs intentionally or unintentionally in an order situation and in accordance to the prevailing rules and regulations as it is currently taking place.

\section{Motivation in Learning}

Learning motivation is an overall psychology driving willing to achieve a goal in learning within the student as individual.

\section{MATERIALS \& METHODS}

This research is a correlation research. 156 students of SMK Putra Harapan of XI grade were the population and 30 students were included as samples selected by the simple random sampling technique. Data collection techniques used in this research was questionnaires and observation sheets. The instrument used is a questionnaire consisting of several statements and questions on each variable. In this research, the questionnaire used was the Likert scale. Before the questionnaire was distributed to the respondents, validity and reliability tests were conducted. The results of the validity test on the variables of parents' economic status, discipline, learning motivation and learning outcomes were stated as valid items, because the r-counted was greater than 0.3. Meanwhile, the reliability test for all variables of parents' economic status, discipline, learning motivation and learning outcomes were declared reliable because the results from the statistics, the alpha value was greater than 0.6. Then the data were analyzed using multiple linear regression analysis techniques.

\section{RESULT}

\section{Research Finding}

The results of the respondent's description show that a total of 30 respondents were taken from class XI students in all majors (OTKP 1, OTKP 2, TITI, TBSM 1, TBSM 2 which were taken equally) at SMK Putra Harapan. Male students are the dominant respondents with an average age of 16-17 years.

\begin{tabular}{lcc}
\multicolumn{3}{c}{ Table 1: Respondent Data by Age } \\
\hline \multicolumn{1}{c}{ Gender } & Number of Respondents & Percentage \\
\hline$<16$ years old & 0 & $0 \%$ \\
\hline 16-17 years old & 25 & $83 \%$ \\
\hline 18-19 years old & 5 & $17 \%$ \\
\hline Total & 30 & $100 \%$ \\
\hline \multicolumn{2}{c}{ Source: Data processed by researchers 2021}
\end{tabular}

From table above it can be known that respondents penelitian who are less than 16 years old do not exist, while those aged 16-17 years there are 25 learners with a percentage of $83 \%$. While those aged 18 19 years there are 5 students with a percentage of $17 \%$. Of the respondents (based on age) Iebih many aged 16-17 years.

\section{Classic Assumption Test Normality test}

From the research result, it is stated that the data has a normal distribution. It can be seen that the decision making has been fulfilled, by showing that the data spreads around and follows the direction of the diagonal line even though there are points that do not follow the diagonal line, but these points return to normal following the distribution pattern on the diagonal line, so that the assumption of normality can be met in the regression mode I.

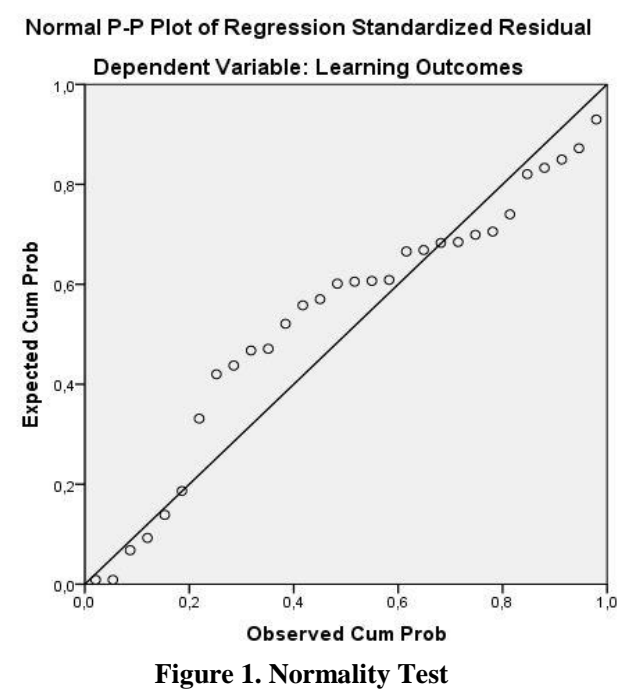


Suci Monika et.al. The influence of social economic status, discipline, motivation on learning outcomes of entrepreneurship creative products.

From the data above the data has been distributed normally. This indicates that the figure has fulfilled the basis of decision making, that the data spreads around the horizontal line and follows the diagonal line direction even though there are points that spread not following the diagonal line but then the point Returns to normal following the diagonal line indicates a normal distribution pattern, then the regression model meets the assumption of normality.

\section{Multicollinearity test}

From the results of the study, it was stated that there was no interference with linearity in the regression mode. It can be seen that all independent variables are in line with the VIF value which is smaller than 10 while 0.10 is greater than the tolerance value of all variables. Thus, there is no indication between the independent variables in the regression mode.

Table 2: Multicollinearity Test Results Coefficients $^{a}$

\begin{tabular}{|c|c|c|c|}
\hline \multirow[b]{2}{*}{ Mode } & & \multicolumn{2}{|c|}{ Collinearity Statistics } \\
\hline & & Tolerance & VIF \\
\hline \multirow[t]{4}{*}{1} & (Constant) & & \\
\hline & Social Economic Status &, 531 & 1,884 \\
\hline & Discipline & .477 & 2,094 \\
\hline & Motivation & .866 & 1,155 \\
\hline
\end{tabular}

Based on the table above can be seen that the regression model does not experience multicollinearity disorders. This indicates the VIF value of all free variables in this study was smaller than 10, while the tolerance value of all variables was greater than 0.10. Thus it can be concluded that there are no symptoms of multicollinearity between free variables in the regression model.

\section{Autocorrelation Test}

From the research results it is stated that the value of Durbin Watson is 1,837. The 5\% significance value in the table value will be compared with the Durbin Watson value (DW test), with the number of 30 samples (n) and $3(\mathrm{k}=3)$ being the number of independent variables, so the upper limit (du) will be 1,649 on the Durbin Watson table. So that 4-du $=4-1.649=2.351$. Then 4 - du is scored up to du on Durbin Watson's value, so that the classic assumption test has been fulfilled and there is no autocorrelation indication in the regression equation.

Based on table 3, it can be seen that the value of Durbin Watson (DW test) is 1,837 . The value will be compared to the table value using a significance value of $5 \%$, the number of samples 30 (n) and independent variable $3 \quad(\mathrm{k}=3)$, then the Durbin Watson table will get the upper limit (du) 1,649. So $4-\mathrm{du}=4-1.649=2.351$. Thus it is known that the value of Durbin Watson is located between du to $4-\mathrm{du}$, so it can be stated that the regression equation has no symptoms of autocorrelation and the classic assumption test has been fulfilled.

Table 3: AutokoreIasi

Model Summary
\begin{tabular}{|l|c|r|c|c|c|}
\hline Model & R & R Square & $\begin{array}{c}\text { Adjusted R } \\
\text { Square }\end{array}$ & $\begin{array}{c}\text { Std. Error of } \\
\text { the Estimate }\end{array}$ & $\begin{array}{c}\text { Durbin- } \\
\text { Watson }\end{array}$ \\
\hline 1 &, $841^{\text {a }}$ &, 707 &, 673 & 9,05684 & 1,837 \\
\hline
\end{tabular}
a. Predictors: (Constant), Motivation, Social Economic Status, Discipline
b. Dependent Variable: Learning Outcomes

Source: SPSS output from primary data 2021

\section{Multiple Linear Regression Test}

Based on the results of multiple linear regression analysis, a constant value of 10.251 was obtained while the value for the social status variable was 0.261, discipline was 0.888 , and motivation was 0.155. So that if it is included in the regression original function as a whole, then 
Suci Monika et.al. The influence of social economic status, discipline, motivation on learning outcomes of entrepreneurship creative products.

the following equation is obtained: $\mathrm{Y}=$ $10.251+0.261 \mathrm{X} 1+0.888 \mathrm{X} 2+(-0.155)+$ $\mathrm{e}$

Tabel 4: Multiple Linear Regression Analysis Results Coefficients $^{\mathrm{a}}$

\begin{tabular}{|c|c|c|c|c|}
\hline \multirow[b]{2}{*}{ Model } & & \multicolumn{2}{|c|}{ Unstandardized Coefficients } & \multirow{2}{*}{$\begin{array}{c}\begin{array}{c}\text { Standardized } \\
\text { Coefficients }\end{array} \\
\text { Beta } \\
\end{array}$} \\
\hline & & B & Std. Error & \\
\hline \multirow[t]{4}{*}{1} & (Constant) & 10,251 & 22,813 & \\
\hline & Social Economic Status &, 261 &, 116 &, 328 \\
\hline & Discipline &, 888 & .228 & .597 \\
\hline & Motivation & -,155 & ,349 & , 051 \\
\hline
\end{tabular}

Source: SPSS output from primary data 2021

The regression equation can be interpreted as an increase in social status, and then 0.261 by one unit will increase learning outcomes with the assumption that other variables have fixed values. And if the increase in discipline is equal to unity, the learning outcome will increase by 0.888 assuming the other variables are of constant value, and if the student's motivation increases by 0.155 , there will be a decrease in the learning outcomes experienced by the participants with the assumption that the other variables have a fixed value.

While the constant of 10.251 means that if the other social status, discipline and motivation are 0 , then the other learning outcomes are 10.251.

\section{The Influence of Parents' Socio-Economic Status on Learning Outcomes}

Based on the results of statistical tests, the calculation shows a significant result of $0.033<0.05$, therefore $\mathrm{H} 0$ is rejected and $\mathrm{Ha}$ is accepted, which means that there is a significant influence between economic status on learning outcomes. The economic status found in the field can be seen from income, the last education held by the parents and the parents of the students' work. It can be interpreted that the income of the parents of students is still classified as lower-middle income. With the last education level, the parents are mostly junior high school graduate and both parents are working. This is in line with the several studies above where when the level of a family's socioeconomic status is in a stable and sufficient condition will affect children's learning outcomes. In other words, this socioeconomic status will affect the teaching and learning process in the form of facilities provided by parents as a form of support in learning.

\section{DISCUSSION}

\section{The Influence of Discipline on Learning Outcomes}

Based on the results of hypothesis testing (H1), it has been confirmed that there is an influence between disciplines on learning outcomes. Based on the results of the calculations that have been carried out, a significant level of the results of 0.001 $<0.05$, thus $\mathrm{H} 0$ is rejected and $\mathrm{Ha}$ is accepted. This test statistically proves that learning discipline has an effect on learning outcomes. Another important factor in enforcing discipline can be to make a priority schedule and do it continuously so that it becomes a habit. So that students do not have any objections in maintaining discipline every day and can have a very effective impact in the learning process of students, so that it will have an effect on learning outcomes.

While discipline at home needs to be suppressed so that discipline at school doesn't feel weighed down, it needs guidance from parents. For example, following the use of attributes provided by the school, not being late for school is an example of regulations that have been set by the school and these can be implemented by respondents. However, actually, most of the respondents are not used to implementing their disciplinary habits at home. This happens because of several arguments like parents are reluctant to apply discipline at home, so that it becomes a habit by respondents at school in conducting lessons and doing other things that will support their discipline at school.

From the results of data analysis, it has been confirmed that there is a significant influence between learning discipline and student learning achievement. It can be said that if the learning discipline 
is higher, the learning achievement also high, and on the other hand, if the learning discipline is low, the learning achievement will be low. This is in line with the theory and previous studies. And in this research, the highest level is for indicators of extracurricular learning discipline in school.

\section{The Influence of Learning Motivation on Learning Outcomes}

In line with the results of hypothesis testing ( $\mathrm{H} 1)$, it has been proven that there is no significant effect on learning outcomes. Through the calculation results obtained a level of $0.660<0.05$, which means that $\mathrm{H} 1$ is accepted and $\mathrm{H} 0$ is rejected. This test statistically proves that learning motivation has no effect on learning outcomes. The results of the analysis show that there is no significant positive effect between the motivational variables on learning outcomes in the subjects of Creative Products and Entrepreneurship. The results of this study are not in line with the previous research conducted by (Indrianti, Djaja, and Suyadi 2018) which states that there is an influence of motivation on student learning outcomes in accounting subjects. Then in research by (Indra Azra 2015) which states that there is a significant influence between motivations on student learning outcomes.

There are differences in the results of this research and previous studies, which can be caused by different school environment conditions, different characteristics of students in each school, and different school quality standards. Not only one factor that affects learning outcomes, but it is influenced by many factors. This statement is in line with the opinion of (Indra Azra 2015) "Internal and external factors are factors that affect learning outcomes. Where are internal factors (intelligence, health, interests, talents, learning methods, motivation) and external factors (school, family, surrounding environment and society)". These factors will be interrelated in achieving direct and indirect learning outcomes. So motivation does not have a direct effect, it can be caused by other factors such as health, intelligence, talent, learning methods, and society.

\section{CONCLUSION}

This study aims to examine the influence of socioeconomic status, discipline, and motivation on learning outcomes at SMK Putra Harapan. Class XI students are the object of this research. Based on the research results and the discussion that has been stated previously, the following conclusions can be drawn:

1. The economic status of parents has a significant influence on the learning outcomes of creative entrepreneurship products subject at SMK Putra Harapan.

2. Learning discipline has a significant influence on learning outcomes for creative entrepreneurship products subject at SMK Putra Harapan.

3. Learning motivation has no significant effect on learning outcomes for creative entrepreneurship products subject at SMK Putra Harapan.

4. Simultaneously, parents' economic status, discipline, and learning motivation significantly influence the learning outcomes of creative entrepreneurship products subject at SMK Putra Harapan.

\section{Acknowledgement: None}

\section{Conflict of Interest: None}

\section{Source of Funding: None}

\section{REFERENCES}

1. Artantri, M. W., Forijati, R. R., Anas, M., \& Surindra, B. (2021). The Development of Digital-Based Economics in Sustaining Interest in Shopping Online through the Marketplaces during the COVID-19 Pandemic, 8(March), 260-268. Retrieved from

https://www.ijrrjournal.com/IJRR_Vol.8_Is sue.3_March2021/IJRR034.pdf

2. Astuti, Apriliya Dwi. 2017. "Pengaruh Motivasi Dan Disiplin Kerja Terhadap Kinerja Guru SD Di Kabupaten CiIacap." 
Suci Monika et.al. The influence of social economic status, discipline, motivation on learning outcomes of entrepreneurship creative products.

$\begin{array}{lrr}\text { JurnaI } & \text { Akuntabilitas } & \text { Manajemen } \\ \text { Pendidikan } & \text { 5(2):150. } & \text { doi: } \\ \text { 10.21831/amp.v5i2.13931. } & \end{array}$

3. Forijati., Anas, M. . E. R. (2020). Meta Analysis; The Influence of Teaching Economy Innovation to the Escalation of The teaching Quality, 6(9), 1-5.

4. Fuadi, A. S., \& Anas, M. (2019). Implementasi Model CIPP dalam Evaluasi Kurikulum 2013 Pendidikan Ekonomi. Prosiding SEMDIKJAR (Seminar Nasional Pendidikan Dan Pembelajaran), 3, 316-324. Retrieved from http://ojs.semdikjar.fkip.unpkediri.ac.id/inde x.php/SEMDIKJAR/article/view/32

5. Indra Azra, Fefri. 2015. "Pengaruh lingkungan Keluarga Dan Motivasi BeIajar Siswa Terhadap HasiI BeIajar Akuntansi Siswa KeIas X Smk Negeri 1 SoIok SeIatan." Economica 2(2):85-98. doi: 10.22202/economica.2014.v2.i2.221.

6. Indrianti, Rufi, Sutrisno Djaja, and Bambang Suyadi. 2018. "Pengaruh Motivasi Dan Disiplin BeIajar Terhadap HasiI BeIajar Mata PeIajaran Prakarya Dan
Kewirausahaan.” JURNAI PENDIDIKAN EKONOMI: JurnaI IImiah IImu Pendidikan, IImu Ekonomi Dan IImu SosiaI 11(2):69. doi: 10.19184/jpe.v11i2.6449.

7. Jayanti, S. N., Amanah, R., Artantri, M., \& Muchson, M. (2021). Micro , Small and medium Enterprises ' Defense among Pandemic Covid-19. International Journal of Advances in Enginering and Management (IJAEM), 3(5), 1318-1326. https://doi.org/10.35629/5252030513181326

8. 1377. No

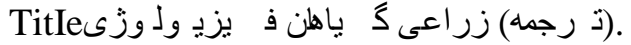

9. (Astuti 2017; Indra Azra 2015; Indrianti et aI. 2018; 5 (1377)

How to cite this article: Monika S, Sugiono, Subagyo, M. Anas. The influence of social economic status, discipline, motivation on learning outcomes of entrepreneurship creative products. International Journal of Research and Review. 2021; 8(7): 304-310. DOI: https://doi. org/10.52403/ijrr.20210742 